\title{
Peptidomimetic antagonists of $\alpha v \beta 3$ inhibit bone resorption by inhibiting osteoclast bone resorptive activity, not osteoclast adhesion to bone
}

\author{
C P Carron, D M Meyer, V W Engleman, J G Rico, \\ P G Ruminski, R L Ornberg, W F Westlin and G A Nickols
} Departments of Discovery Pharmacology, Medicinal Chemistry and Oncology, Searle Research and Development, Monsanto Company, St Louis, Missouri,
63198, USA
(Requests for offprints should be addressed to C P Carron, Monsanto Co. AA5I, Searle Research and Development, 700 Chesterfield Village Pkwy, St Louis,
Missouri 63198, USA; Email: chris.p.carron@monsanto.com)

\begin{abstract}
Osteoclasts are actively motile on bone surfaces and undergo alternating cycles of migration and resorption. Osteoclast interaction with the extracellular matrix plays a key role in the osteoclast resorptive process and a substantial body of evidence suggests that integrin receptors are important in osteoclast function. These integrin receptors bind to the Arg-Gly-Asp (RGD) sequence found in a variety of extracellular matrix proteins and it is well established that the interaction of osteoclast $\alpha v \beta 3$ integrin with the RGD motif within bone matrix proteins is important in osteoclast-mediated bone resorption. In this study, we characterized the effects of two synthetic peptidomimetic antagonists of $\alpha v \beta 3, \mathrm{SC}-56631$ and SC65811, on rabbit osteoclast adhesion to purified matrix proteins and bone, and on bone resorption in vitro. SC-56631 and SC-65811 are potent inhibitors of vitronectin binding to purified $\alpha v \beta 3$. Both SC-56631 and SC-65811 inhibited osteoclast adhesion to osteopontinand vitronectin-coated surfaces and time-lapse video
\end{abstract}

microscopy showed that osteoclasts rapidly retract from osteopontin-coated surfaces when exposed to SC-56631 and SC-65811. SC-56631 and SC-65811 blocked osteoclast-mediated bone resorption in a dose-responsive manner. Further analysis showed that SC-65811 and SC-56631 reduced the number of resorption pits produced per osteoclast and the average pit size. SC-65811 was a more potent inhibitor of bone resorption and the combination of reduced pit number and size led to a $90 \%$ inhibition of bone resorption. Surprisingly, however, osteoclasts treated with SC-65811, SC-56631 or the disintegrin echistatin, at concentrations that inhibit bone resorption did not inhibit osteoclast adhesion to bone. These results suggest that $\alpha v \beta 3$ antagonists inhibited bone resorption by decreasing osteoclast bone resorptive activity or efficiency but not by inhibiting osteoclast adhesion to bone per se.

Journal of Endocrinology (2000) 165, 587-598

\section{Introduction}

Osteoclasts attach to the bone surface and develop polarized and specialized cell membrane areas. The osteoclast ruffled border and circumferential sealing zone juxtaposed with the bone surface define the limits of the resorption pit. The sealing zone forms a tight attachment of the cell membrane to the bone surface isolating the resorption lacunae from the extracellular environment, permitting development and maintenance of an acidic, protease-rich microenvironment favorable for bone degradation (Horton \& Rodan 1996).

Osteoclasts actively migrate on bone surfaces and undergo alternating cycles of migration and resorption (Kanehisa \& Heersche 1988, Lakkakorpi \& Vaananen 1991). Ruffled borders and sealing zones are seen only in non-motile osteoclasts during the resorption phase and subsequently disappear during the course of osteoclast migration (Kanehisa \& Heersche 1988). Osteoclast interaction with extracellular matrix (ECM) plays a key role in the migratory and resorptive phases of the osteoclast cycle and a substantial body of evidence suggests that integrin receptors play a key role in the osteoclast resorption process (Horton \& Rodan 1996).

Integrins are transmembrane $\alpha / \beta$ heterodimers that mediate cellular interactions with other cells and ECM components. The integrin family contains at least $12 \alpha$ subunits that associate with at least nine $\beta$ subunits, producing a variety of heterodimer combinations with different cell expression patterns and ligand-binding activity. Many integrins bind to the Arg-Gly-Asp (RGD) consensus sequence found in a variety of ECM proteins 
(Ruoslahti 1996). Bone contains a variety of RGDcontaining proteins including collagen, thrombospondin, fibronectin, vitronectin, osteopontin and bone sialoprotein (Cheresh \& Spiro 1987, Butler 1989, Clezardin et al. 1989, Robey et al. 1989, Reinholt et al. 1990) and it is clear that the interaction of osteoclast integrins with the RGD motif within bone matrix proteins plays an important role in osteoclast-mediated bone resorption (Cheresh \& Spiro 1987, Butler 1989, Clezardin et al. 1989, Robey et al. 1989, Reinholt et al. 1990, Flores et al. 1992, Helfrich et al. 1992, Ross et al. 1993, Grano et al. 1994, Rodan \& Rodan 1997).

Osteoclasts express high levels of $\alpha v \beta 3$ (the vitronectin receptor), $\alpha 2 \beta 1$ (the collagen/laminin receptor) and $\alpha v \beta 1$ (Horton \& Rodan 1996). Horton and colleagues were the first to demonstrate that integrins play an important role in osteoclastic bone resorption (Chambers et al. 1986, Davies et al. 1989). These investigators showed that the monoclonal antibody 13C2 recognized the osteoclast integrin receptor $\alpha v \beta 3$ and blocked bone resorption in vitro. Various studies have shown that RGD peptides, disintegrins, anti- $\alpha v \beta 3$ antibodies and RGD-peptidomimetic antagonists of $\alpha v \beta 3$ inhibit osteoclast adhesion to surfaces coated with RGD-containing proteins, detach adherent osteoclasts from surfaces coated with matrix protein and prevent bone resorption in vitro and in vivo (Sato et al. 1990, 1994, Horton et al. 1991, 1993, Helfrich et al. 1992, Chuntharapai et al. 1993, Fisher et al. 1993, Ross et al. 1993, King et al. 1994, Crippes et al. 1996, Engleman et al. 1997. Masarachia et al. 1998, Yamamoto et al. 1998). These results demonstrate that $\alpha v \beta 3$ plays a critical role in osteoclast-mediated bone resorption, although its precise role in the process is not yet understood.

The purpose of the present studies was to characterize the effects of two synthetic peptidomimetic antagonists of $\alpha \mathrm{v} \beta 3, \mathrm{SC}-56631$ and SC-65811, on bone resorption in vitro. In agreement with previous studies (Sato et al. 1990, 1994, Horton et al. 1991, Fisher et al. 1993, Ross et al. 1993, King et al. 1994, Crippes et al. 1996, Engleman et al. 1997, Masarachia et al. 1998, Yamamoto et al. 1998) we show that $\alpha v \beta 3$ antagonists inhibit osteoclast adhesion to purified bone matrix protein and osteoclast-mediated bone resorption. However, we found that these same inhibitors do not significantly inhibit osteoclast adhesion to bone. We conclude that $\alpha v \beta 3$ antagonists inhibit bone resorption by inhibiting osteoclastic bone resorptive activity but not by inhibiting osteoclast adhesion to bone per se, suggesting that the role of $\alpha v \beta 3$ integrin in osteoclast bone resorption is more complex than previously believed.

\section{Materials and Methods}

\section{Reagents}

Human plasma was obtained from the American Red Cross (St Louis, MO, USA). Frozen human placentas were obtained from the Department of Pathology, Jewish Hospital (St Louis, MO, USA). NHS-biotin was from Pierce Chemical Company (Rockford, IL, USA). Tris buffer, O-phenylenediamine (OPD) substrate tablets and RIA grade BSA were obtained from Sigma (St Louis, MO, USA). Peroxidase-labeled and affinity-purified anti-biotin antibody was obtained from Calbiochem (San Diego, CA, USA). Pentex BSA fraction $\mathrm{V}$ was used in both cell adhesion and bone resorption assays and pre-screened to demonstrate that osteoclasts did not adhere to plastic surfaces coated with protein (Cat No. 81-053-1, lot No. 40; Miles, Kanakee, IL, USA). $\alpha$-MEM was obtained from Sigma; penicillin and streptomycin were obtained from Gibco Brl (Grand Island, NY, USA).

The $\alpha v \beta 3$ antagonists $\beta-[2-[[5-[[$ aminoiminomethyl] amino]-1-oxopentyl]amino]-1-oxoethyl]amino-3-pyridine propanoic acid, bistrifluoroacetate (SC-56631; see Engleman et al. 1997, Carron et al. 1998, Wong et al. 1998) and $\beta$-[[1-oxo-2-[[[3-[[[(phenylmethyl)amino]carbonyl] amino] phenyl]carbonyl]amino] ethyl]amino]-pyridine-3-propanoic acid, trifluoroacetate salt (SC-65811) were synthesized and obtained from the Department of Medicinal Chemistry, G D Searle (St Louis, MO, USA).

\section{Purification of proteins}

Human vitronectin fibrinogen and osteopontin were purified and biotinylated as previously described (Engleman et al. 1997). Full-length human osteopontin cDNA was expressed in E. coli as a $6 \times$ His-fusion protein using the QIA express $\mathrm{pQE}$ expression system as described by the manufacturer (Qiagen, Chatsworth CA, USA). Osteopontin was purified by nickel-nitriloacetic acid agarose affinity chromatography according to the manufacturer's recommendations (Qiagen) and then further purified by MonoQ (Pharmacia, Piscataway, NJ, USA) chromatography. Integrin $\alpha \mathrm{v} \beta 3$ and the platelet receptor $\alpha \operatorname{IIb} \beta 3$ were purified from human placenta and outdated platelets, respectively, as previously described (Pytela et al. 1987, Engleman et al. 1997).

\section{Solid-phase receptor assay}

SC-56631 and SC-65811 binding to $\alpha \mathrm{v} \beta 3$ and $\alpha \operatorname{IIb} \beta 3$ were characterized using a solid-phase competitive displacement assay as previously described (Engleman et al. 1997). Briefly, 96-well plates were coated with purified human vitronectin receptor $(\alpha v \beta 3)$ or human fibrinogen $(\alpha I I \beta 3)$ receptor. Plates were washed with Tris-buffered saline containing $1 \mathrm{mM} \mathrm{Ca}^{2+}, \mathrm{Mg}^{2+}$, and $\mathrm{Mn}^{2+}, \mathrm{pH} 7 \cdot 4$ (TBS +++ ) and blocked with $\mathrm{TBS}+++$ containing $1 \%$ BSA before use. Serial dilutions of SC-56331 and SC65811 were diluted in $2 \mathrm{nM}$ biotinylated vitronectin in TBS $+++/ 0 \cdot 1 \%$ BSA and then added to plates coated with integrin receptor. The plates were washed with TBS $+++/ 0 \cdot 1 \%$ BSA and bound biotinylated vitronectin 
detected with affinity-purified horseradish peroxidase (HRP)-labeled goat anti-biotin by incubation with HRP substrate $\left(\mathrm{OPD} / \mathrm{H}_{2} \mathrm{O}_{2}\right.$ in $100 \mathrm{mM}$ citrate buffer, $\mathrm{pH}$ 5.0) and the absorbance measured at $450-630 \mathrm{~nm}$.

\section{Isolation of rabbit osteoclasts}

Animal work was carried out in the G D Searle animal facility in accordance with institutional guidelines. All animal procedures were approved by the Institutional Animal Care and Use Committee and conform to the NIH Guidelines for the Ethical Care and Treatment of Animals. Animals were killed by decapitation and bone cells were isolated from the long bones of 2- to 6-day-old rabbits using sterile techniques. Rabbit osteoclasts were obtained as previously described (Kanehisa \& Heersche 1988). Long bones were dissected free of soft connective tissues and the cartilaginous epiphyseal portions removed with a scalpel in ice-cold $\alpha$-MEM containing 1\% BSA, $100 \mathrm{U} / \mathrm{ml}$ penicillin and $100 \mathrm{U} / \mathrm{ml}$ streptomycin and kept on ice. The remaining metaphyseal portions were flushed with media and the bones were curretted and minced in $100 \mathrm{~mm}$ sterile bacteriological grade plastic Petri dishes and transferred to $50 \mathrm{ml}$ conical centrifuge tubes. Cells and bone were triturated repeatedly in $25 \mathrm{ml}$ media/rabbit to remove adherent cells, the bone fragments were allowed to settle for $5 \mathrm{~min}$ and the osteoclast-containing supernatant was used for experiments.

\section{Osteoclast adhesion assay}

Bovine femurs were obtained fresh and then stored frozen $\left(-20^{\circ} \mathrm{C}\right)$. Cortical bone slices were cut using a low-speed diamond saw (Isomet Buehler Ltd, Lake Bluff, IL, USA) and $6 \mathrm{~mm}$ discs were punched out, sterilized and sonicated in $70 \%$ ethanol and then stored frozen until required for use. Bone discs were incubated in $\alpha$-MEM containing $1 \%$ BSA, $100 \mathrm{U} / \mathrm{ml}$ penicillin and $100 \mathrm{U} / \mathrm{ml}$ streptomycin at $37^{\circ} \mathrm{C}$ and $7 \% \mathrm{CO}_{2}$, for $1 \mathrm{~h}$ before use. Osteopontincoated Costar 96-well plates and wells containing $6 \mathrm{~mm}$ circular bone slices were incubated in $\alpha$-MEM containing $1 \% \mathrm{BSA}$ and $20 \mathrm{mM}$ HEPES buffer for $1 \mathrm{~h}$ at $37^{\circ} \mathrm{C}$; one $6 \mathrm{~mm}$ circular bone disc completely occupied the surface area of a Costar 96-well plate. Osteoclasts were diluted in $\alpha-\mathrm{MEM}$ containing various concentrations of SC-56631, SC-65811 or echistatin (BACHEM, Torrance CA, USA) and added to osteopontin-coated wells or wells containing bone and incubated for $60 \mathrm{~min}$ at $37^{\circ} \mathrm{C}$. A tartrateresistant acid phosphatase (TRAP) microtiter assay was used to quantitate the number of osteoclasts bound to osteopontin-coated plates or to bone slices (Minkin 1982, Collin-Osdoby et al. 1995). The plates were washed three times with PBS to remove unbound cells. One hundred microliters soluble TRAP substrate buffer ( $n$-nitrophenyl phosphate (NPP)/tartrate lysis buffer: $50 \mathrm{mM}$ sodium acetate $\mathrm{pH} 5 \cdot 0,0 \cdot 5 \%$ Triton X-100, $0.25 \mathrm{mg} / \mathrm{ml} \mathrm{NPP}$,
$6.7 \mathrm{mM}$ tartrate) were added to the wells and the plates incubated for $1 \mathrm{~h}$ at $37^{\circ} \mathrm{C}$. Fifty microliters $0.1 \mathrm{~N} \mathrm{NaOH}$ were added to each well and the absorbance at $405 \mathrm{~nm}$ determined. The number of bound osteoclasts was determined by comparison with a standard curve. Various numbers of osteoclasts were plated in osteopontin-coated wells and then fixed and stained for cellular TRAP activity and the cell number counted. Osteoclasts were defined as multinucleated ( $\geq 3$ nuclei/cell), TRAP+ cells. Duplicate wells were incubated with NPP/tartrate lysis buffer. A standard curve was generated by plotting the number of osteoclasts against absorbance at $405 \mathrm{nM}$.

\section{Video microscopy of live rabbit osteoclasts}

Osteoclast suspensions were added to dishes containing sterile glass coverslips coated with vitronectin $(10 \mu \mathrm{g} / \mathrm{ml})$. Coverslip cultures were mounted in an open perfusion microincubator stage (Medical Systems, Greenvale, NY, USA) for phase microscopy. Time-lapse video phase contrast microscopy was performed on a Nikon Diaphot 200 inverted light microscope equipped with CCD camera and signal processor (Dage-MTI, Michigan City, IN, USA) attached to a workstation-based analytical imaging system (Inovision Corp., Raleigh, NC, USA). Typically, sequential images obtained with $10 \times, 20 \times$, or $40 \times$ objectives were acquired and stored to disk at 10-30 s intervals for periods up to $30 \mathrm{~min}$. Test articles were added after the first four or five frames. Montage images from selected time points were assembled to demonstrate the effect of various treatments.

\section{Quantitative pit resorption assay}

Bone slices were transferred to 12 -well plates, $0.5 \mathrm{ml}$ osteoclast-containing cell suspension were added and the cells allowed to settle for $2 \mathrm{~h}$ at $37^{\circ} \mathrm{C}$. Bone pieces were rinsed to remove non-adherent cells and transferred to fresh media and incubated for 2 or 3 days. In some experiments, the $\alpha v \beta 3$ antagonist was added to the suspension and the cells were plated on bone in the presence of compound; in other cases, compound was added $2 \mathrm{~h}$ after cell plating (see figure legends for details). In other instances, $\alpha v \beta 3$ antagonist was added to the suspension, the cells were plated on bone in the presence of test compound, incubated for $6 \mathrm{~h}$ and then transferred to fresh media or fresh media containing compound and incubated for an additional 3 days.

Osteoclasts cultured on bones slices were rinsed with Hanks' balanced salt solution, $\mathrm{pH} 7 \cdot 2$ (HBSS), fixed in 1\% formalin/HBSS, rinsed and stained for TRAP according the manufacturer's recommendations (Sigma, St Louis MO, USA). The number of TRAP+, multinucleated cells for each treatment was obtained by examination of 10 random fields per bone disc. Two bone pieces were used for each compound and concentration tested. Bone pieces 


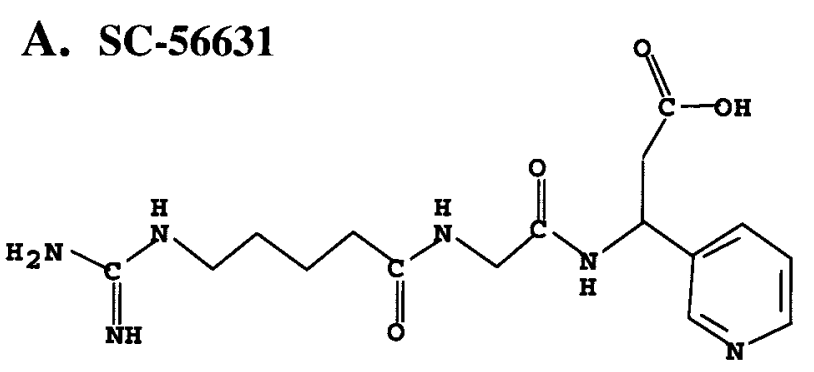

\section{B. SC-65811}

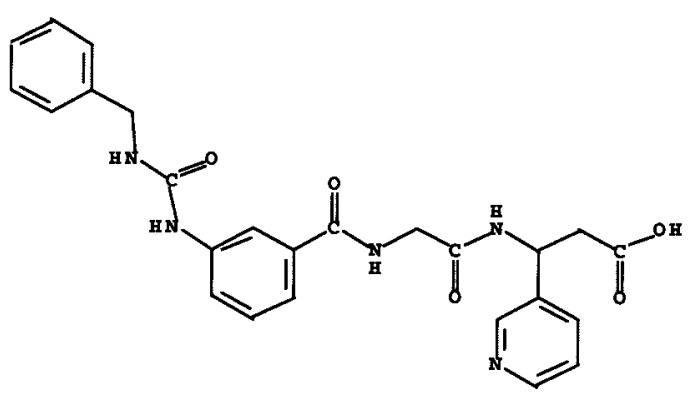

Figure 1 Structures of synthetic chemical Arg-Gly-Asp (RGD) mimetics: the peptidomimetic antagonists $\beta$-[2-I[5[(aminoiminomethyl)amino]-1-oxopentyl]amino]-1oxoethyl]amino-3-pyridinepropanoic acid, bistrifluoroacetate (SC-56631) and $\beta$-[[1-oxo-2-[[[3-[[[(phenylmethyl)amino] carbonyl]amino]phenyl]carbonyl]amino]ethyl]amino]-pyridine3-propanoic acid, trifluoroacetate salt (SC-65811).

were then washed in $10 \mathrm{mM} \mathrm{NH}_{4} \mathrm{OH}$ to remove cells and the number and area of resorption pits quantitated using dark-field reflective microscopy. Osteoclast number and the number and area of resorption pits were measured and recorded. All measurements were performed on videocaptured images linked to a Leica Quantimet image analysis program.

\section{Data evaluation}

Data are expressed as means \pm S.E.M. Statistical significance was determined using the InStat software package (GraphPad Software Inc., San Diego, CA, USA).

\section{Results}

\section{Identification of $R G D$ peptidomimetic inhibitors of $\alpha v \beta 3$}

Figure 1 shows the two $\alpha v \beta 3$ antagonists: $\beta-[2-[[5-$ [[aminoiminomethyl]amino]-1-oxopentyl]amino]-1-oxoethyl]amino-3-pyridinepropanoic acid, bistrifluoroacetate (SC-56631) and $\beta$-[[1-oxo-2-[[[3-[[[(phenylmethyl]amino] carbonyl]amino]phenyl]carbonyl]amino]ethyl]amino]pyridine-3-propanoic acid, trifluoroacetate salt (SC65811).

As seen in Fig. 2, SC-56631 inhibited both vitronectin binding to $\alpha v \beta 3$ and fibrinogen binding to $\alpha \operatorname{IIb} \beta 3$ in a dose-responsive manner with $\mathrm{IC}_{50}$ values of $4.8 \mathrm{nM}$ and $5.9 \mathrm{nM}$ respectively. In contrast, $\mathrm{SC}-65811$ was a more selective inhibitor of $\alpha \mathrm{v} \beta 3$ and inhibited vitronectin binding to $\alpha \mathrm{v} \beta 3$ in a dose-responsive manner with an $\mathrm{IC}_{50}$ of $0.8 \mathrm{nM}$. SC-65811 was much less potent as an inhibitor of $\alpha \operatorname{IIb} \beta 3$ binding to fibrinogen and inhibited $\alpha \operatorname{IIb} \beta 3$ binding to fibrinogen with an $\mathrm{IC}_{50}$ of $3100 \mathrm{nM}$.

\section{Inhibition of osteoclast adhesion to osteopontin}

The $\alpha v \beta 3$ antagonists SC-56631 and SC-65811 inhibited rabbit osteoclast attachment to surfaces coated with osteopontin. Figure 3 shows that SC-65811 inhibited osteoclast adhesion with an $\mathrm{IC}_{50}$ of approximately $2 \mu \mathrm{M}$ and was approximately 10 -fold more potent than SC-56631. These results are consistent with the data in Fig. 2 showing that SC-65881 was 6-fold more potent than SC-56631 as an inhibitor of $\alpha v \beta 3$ binding to vitronectin. Identical results were obtained when serum- or vitronectin-coated surfaces were substituted in place of osteopontin (data not shown).

Figure 4 shows representative results demonstrating the effect of SC-65811 on osteoclasts that were adherent to glass surfaces coated with purified vitronectin. Osteoclasts were plated on vitronectin-coated glass coverslips for $18 \mathrm{~h}$ and then the coverslips were mounted in an open perfusion microincubator stage for time-lapse video phase microscopy. Tissue culture media were replaced with fresh media containing SC-65811 $(20 \mu \mathrm{M}$ final concentration) and recording (1 frame/30 s) commenced immediately. Figure 4 shows that osteoclasts rapidly rounded up and retracted on the addition of SC-65811. Initial shape change was detected within $2 \mathrm{~min}$ and retraction appeared to be complete by $15 \mathrm{~min}$. In contrast, adherent contaminating fibroblast-like cells remained well spread and did not appear to respond to the addition of SC-65811 over the course of the experiment. Similar results were obtained when SC-56631 was used in place of SC-65811 (data not shown). Taken together, the results shown in Figs 2 and 3 suggest that, like echistatin and other RGD-containing peptides (Flores et al. 1992, Horton et al. 1993, Ross et al. 1993), the $\alpha v \beta 3$ peptidomimetic antagonists SC-56631 and SC-65811 block osteoclast interaction with the ECM.

\section{In vitro bone resorption}

To test the concept that $\alpha \mathrm{v} \beta 3$ antagonists inhibit bone resorption by blocking osteoclast adhesion to bone, osteoclasts were plated on bone slices in media containing either vehicle or SC-65811. Osteoclasts were plated in $20 \mu \mathrm{M}$ SC-65811 for $6 \mathrm{~h}$ and then the bone slices were either 


\section{A. SC-56631}

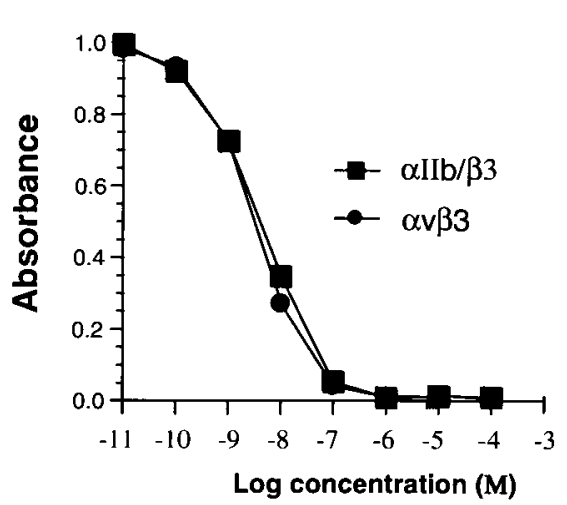

\section{B. SC-65811}

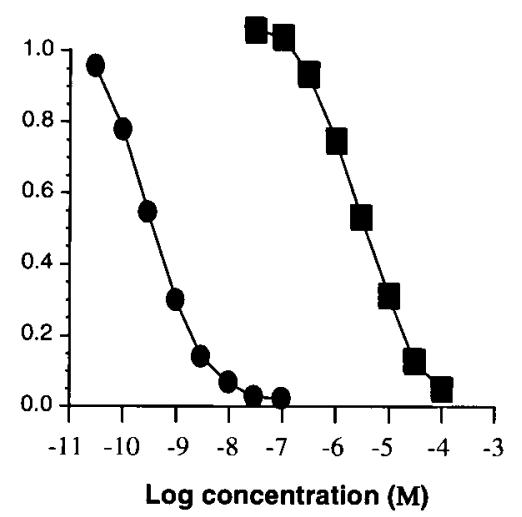

Figure 2 SC-56631 and SC-65811 are potent inhibitors of vitronectin binding to the integrin $\alpha v \beta 3$. Integrins $\alpha v \beta 3$ or $\alpha$ llb $\beta 3$ were incubated with $2 \mathrm{nM}$ biotinylated vitronectin in the presence of various concentrations of SC-56631 and SC-65811. Bound vitronectin was detected with peroxidase-labeled goat anti-biotin antibody. Each data point represents the mean of three independent determinations and the error bars indicate the standard deviation of the mean.

transferred to wells containing fresh media and SC-65811 and incubated for an additional 3 days, or washed twice with fresh media to remove compound and non-adherent cells and then transferred to wells containing fresh media lacking SC-65811 and incubated for an additional 3 days. Bone pieces were fixed and TRAP-stained and the resorptive pit area and number were quantitated by computer-assisted image analysis. We anticipated that osteoclasts plated on bone slices in the presence of SC65811 at concentrations that inhibit osteoclast adhesion to surfaces coated with purified ECM protein would prevent osteoclast adhesion to bone and, as a consequence, bone resorption. Figure 5 shows that continuous treatment of cells with SC-65811 blocked bone resorption by $90 \%$ $(P<0.001)$ compared with osteoclasts treated with vehicle. Osteoclasts plated on bone slices in media containing vehicle resorbed $17112 \mu \mathrm{m}^{2}$ bone/field, whereas osteoclasts plated on bone in the presence of $20 \mu \mathrm{M}$ SC- 65811 and maintained in SC-65811 for the duration of the experiment resorbed $1679 \mu \mathrm{m}^{2}$ bone/field. Surprisingly, osteoclasts that were plated on bone in media containing SC-65811 for $6 \mathrm{~h}$, washed to remove compound and incubated in fresh media for an additional 3 days resorbed $13271 \mu \mathrm{m}^{2}$ bone/field. These results suggested that the bone resorptive activity was not significantly affected by transient exposure to SC-65811 $\left(17112 \mu \mathrm{m}^{2}\right.$ compared with $\left.13271 \mu^{2} ; P>0 \cdot 05\right)$. However, continuous treatment of osteoclasts with SC-65811 reduced the number of resorption pits produced by $67 \%$ (from 128 pits to 43 pits; $P<0.01$ ) and average resorptive pit area by $70 \%$ (from $114 \mu \mathrm{m}^{2}$ to $\left.34 \mu \mathrm{m}^{2} ; P<0 \cdot 01\right)$ compared with vehicletreated cells (data not shown). These results suggest that
SC-65811 inhibition of bone resorption resulted from the production of smaller and fewer resorption pits.

To investigate whether osteoclasts adhere to bone in the presence of $\alpha v \beta 3$ antagonists, osteoclasts were added to wells containing bone pieces in the presence of SC-56631 or SC-65811, incubated for $2 \mathrm{~h}$, and the bone pieces with adherent cells transferred to fresh wells and media containing $\alpha v \beta 3$ antagonist and incubated for an additional 3 days. Cells and bone pieces were fixed, TRAP-stained and the number of osteoclasts and the resorption pit area and number quantified by computer-assisted image analysis. Not surprisingly, SC-56631 and SC-65811 inhibited bone resorption in a dose-dependent manner (Fig. 6). Compared with vehicle-treated osteoclasts, SC-65811 inhibited bone resorption by $54 \%(P>0 \cdot 05), 79 \%(P<$ $0 \cdot 001)$ and $88 \%(P<0 \cdot 001)$ at $1 \mu \mathrm{M}, 10 \mu \mathrm{M}$ and $100 \mu \mathrm{M}$ respectively. SC-56631 inhibited bone resorption less potently than SC-65811 (Fig. 6). Compared with vehicletreated osteoclasts, SC-56631 significantly inhibited resorption by $53 \%$ at $100 \mu \mathrm{M}(P<0 \cdot 05)$. In spite of the fact that osteoclasts were added to bone slices in the presence of $\alpha v \beta 3$ antagonists, SC-56631 and SC-65811 did not significantly reduce the number of osteoclasts adherent to bone: the number of osteoclasts adherent to bone slices treated with $\alpha v \beta 3$ antagonist or vehicle was not significantly different at any concentration of SC-56631 or SC-65811 that was tested (Kruskal-Wallis test, $P=0 \cdot 166$ ).

Because these results suggested that SC-56631 and SC-65811 inhibited bone resorption by interfering with aspects of osteoclast resorption other than by simply inhibiting osteoclast adhesion to bone, we considered whether SC-65811 treatment inhibited bone resorption, 


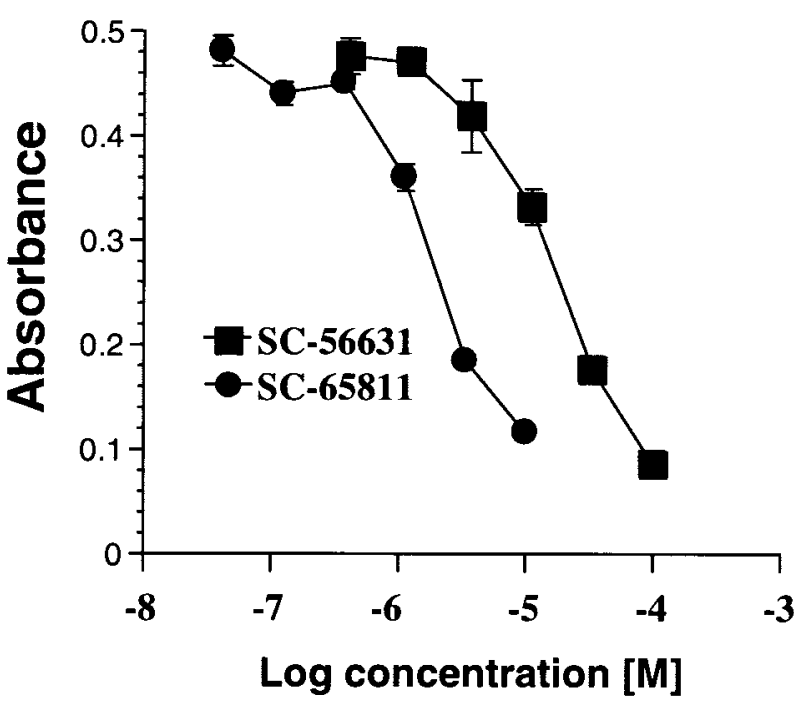

Figure 3 SC-56631 and SC-65811 inhibit rabbit osteoclast adhesion to osteopontin. Osteoclasts suspensions were combined with various concentrations of SC-56631 and SC-65811 diluted in $\alpha$-MEM containing $1 \%$ BSA, added to osteopontin-coated wells $(5 \mu \mathrm{g} / \mathrm{ml})$ and incubated at $37^{\circ} \mathrm{C}$ for $1 \mathrm{~h}$. The plates were washed to remove non-adherent cells and TRAP substrate (NPP/tartrate lysis buffer: $50 \mathrm{mM} \mathrm{Na}$ acetate, $\mathrm{pH} 5 \cdot 0,0 \cdot 5 \%$ Triton X-100, $0.25 \mathrm{mg} / \mathrm{ml} \mathrm{NPP}, 6.7 \mathrm{mM}$ tartrate) was added, the plates incubated for $1 \mathrm{~h}$ at $37^{\circ} \mathrm{C}$, and absorbance measured $405 \mathrm{nM}$. Osteoclasts were defined as multinucleated ( $\geq 3$ nuclei/cell), TRAP+ cells. A standard curve was generated by plotting number of osteoclasts against absorbance at $405 \mathrm{nM}$. Each data point represents the mean of three determinations and the error bars represent the mean \pm S.E.M.

in the experiment described above, by decreasing osteoclast resorptive activity or efficiency. Data in Table 1 show that plating osteoclasts on bone slices in the presence of SC-65811 produced fewer and smaller resorption pits per osteoclast in a dose-dependent manner. Compared with vehicle-treated osteoclasts, those treated with SC-65811 decreased the number of resorption pits produced by $31 \%(P>0 \cdot 05), 77 \%(P<0 \cdot 001)$ and 69\% $(P<0 \cdot 001)$, the number of pits produced per osteoclast by $10 \%, 65 \%$ and $58 \%$, and the resorption pit area produced per osteoclast by $41 \%, 69 \%$ and $83 \%$, at $1 \mu \mathrm{M}, 10 \mu \mathrm{M}$ and $100 \mu \mathrm{M}$ respectively. Together, these data indicated that SC-65811 inhibited osteoclast bone resorptive activity, but not osteoclast adhesion to bone, in a dose-dependent manner. Further, multiple regression analysis of the relationship between osteoclast cell number, dose of SC-65811 and pit area failed to demonstrate a statistically significant relationship between pit area and cell number at any dose of SC-65811 tested. Similar results were obtained when SC-56631 was used in place of SC-65811 and in other experiments in which cells were plated on bone slices in the absence of compound and then transferred to fresh media containing either SC-56631 or SC-65811 (data not shown).
Inhibition of osteoclast adhesion to osteopontin or bone discs

To test and compare SC-56631 and SC-65811 directly as inhibitors of osteoclast adhesion to bone and ECM, osteoclasts were diluted in $\alpha$-MEM containing SC-56631 $(100 \mu \mathrm{M})$, SC-65811 $(100 \mu \mathrm{M})$ or echistatin $(100 \mathrm{nM})$ and added to osteopontin-coated 96-well plates or to wells containing $6 \mathrm{~mm}$ bone discs. The cells were incubated at $37^{\circ} \mathrm{C}$ for $1 \mathrm{~h}$ and then the wells were washed to remove non-adherent cells. The number of bound osteoclasts was determined as described in the Materials and Methods. Figure 7 shows that SC-56631, SC-65811 and echistatin inhibited completely the binding of osteoclasts to osteopontin-coated wells, but did not inhibit osteoclast adhesion to bone slices.

\section{Discussion}

Osteoclasts migrate on the bone surface and initiate the resorption process in cycles of migration and resorption (Kanehisa \& Heersche 1988, Lakkakorpi \& Vaananen 1991). Adhesion molecules and integrin receptors are believed to play a role in various steps of the osteoclast resorption cycle. There is now a significant body of evidence that suggests that antagonists of the integrin $\alpha v \beta 3$ may provide an effective therapeutic approach for the treatment of excessive osteoclast activity and bone loss in osteoporosis, metastatic bone disease or Paget's disease (Horton \& Rodan 1996).

Chambers and coworkers (1986) and Davies and colleagues (1989) were the first to implicate integrins in the process of bone resorption. These workers showed that a monoclonal antibody, $13 \mathrm{C} 2$, raised against rat osteoclasts recognized $\alpha v \beta 3$ and inhibited bone resorption in vitro. Many of the known integrins, including $\alpha v \beta 3$, bind to the Arg-Gly-Asp (RGD) consensus sequence found in ECM ligands. Subsequent work by a number of investigators showed that synthetic RGD-based peptides, in addition to the RGD-containing disintegrins inhibit osteoclast binding to immobilized ECM proteins (Flores et al. 1992, Helfrich et al. 1992, Ross et al. 1993, Sato et al. 1994) and bone resorption in vitro (Sato et al. 1990, 1994). Fisher and colleagues (1993) showed that the RGD-containing disintegrin echistatin inhibited osteoclast-mediated bone resorption in the thyroparathyroidectomized rat. More recently, Crippes et al. (1996) showed that a monoclonal antibody that recognizes and neutralizes $\alpha v \beta 3$ blocked the osteoclast-mediated bone resorption in the same model. In addition, Engleman et al. (1997) and Yamamoto et al. (1998) and others (Masarachia et al. 1998) have shown that the RGD peptidomimetic SC-56631 and echistatin inhibited bone loss in ovariectomized rodents.

In an effort to develop a non-toxic small-molecule pharmacologic antagonist of integrin $\alpha v \beta 3$, peptidomimetic inhibitors of $\alpha v \beta 3$ were identified and modified to enhance potency and selectivity. Integrin selectivity was 

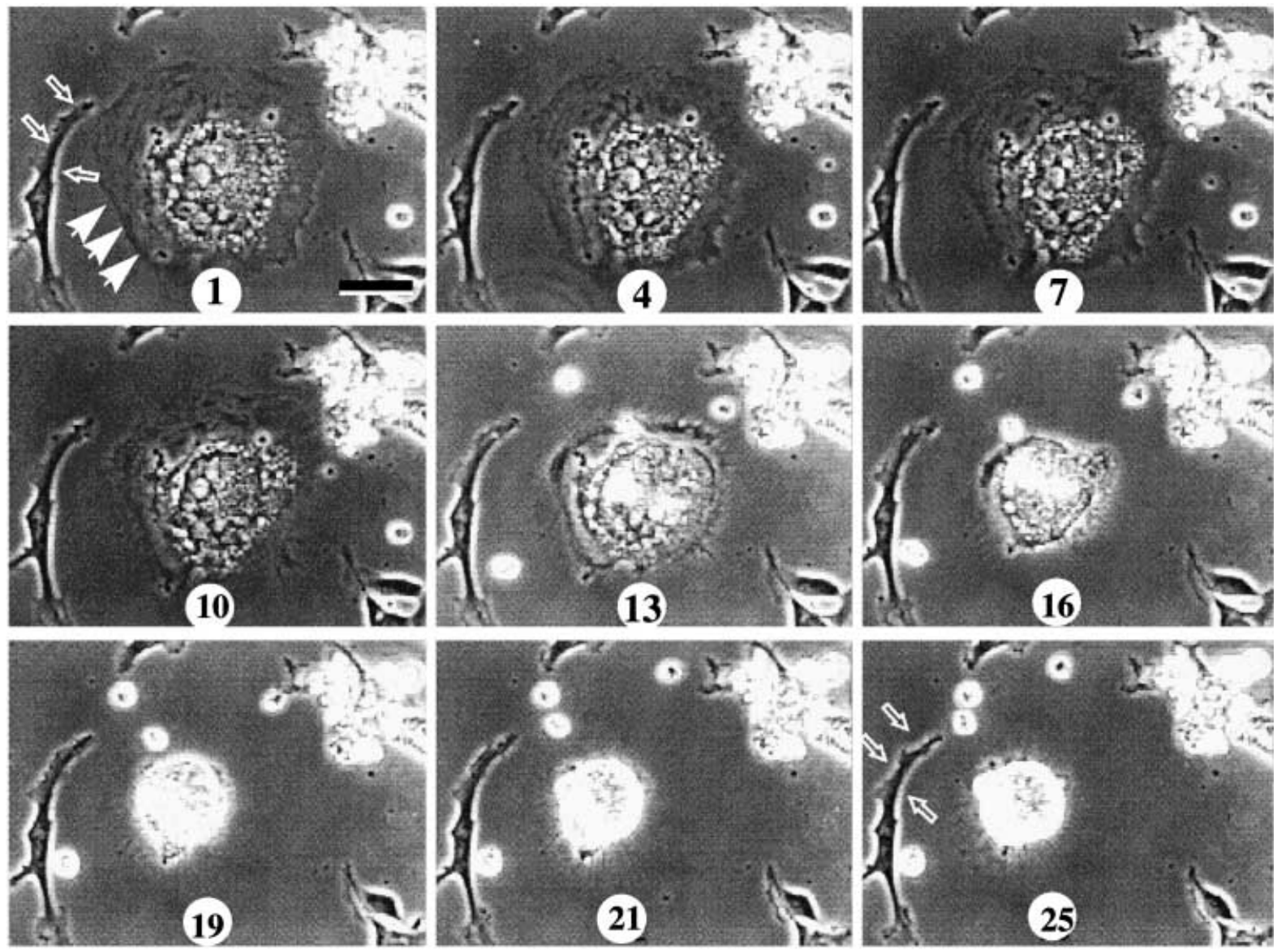

Figure 4 SC-65811-induced retraction of osteoclasts adherent to vitronectin. Osteoclasts were plated on vitronectin-coated glass coverslips for $18 \mathrm{~h}$ and the coverslips were examined by time-lapse video microscopy. Tissue culture media were replaced with fresh media containing SC-65811 (20 $\mu \mathrm{M}$ final concentration) and images were acquired and stored to disk at 30-s intervals. Frames 1-25 show the effects of SC-65811 on a single osteoclast. Frame 1 was captured $30 \mathrm{~s}$ after addition of SC-65811; frames 4-25 were acquired at 90-s intervals thereafter. The osteoclast in frame 25 had been incubated in SC-65811 for 12.5 min at the time that this image was acquired. The solid arrows in frame 1 indicate the margin of the osteoclast. The open arrows in frames 1 and 25 point to a fibroblast of which the morphology was only minimally changed over the course of the experiment. Bar represents $20 \mu \mathrm{m}$.

considered important because RGD-binding integrins are widely distributed and participate in various physiologic and pathologic processes. Of particular concern was the platelet fibrinogen receptor, $\alpha \operatorname{IIb} \beta 3$. Integrins $\alpha \operatorname{IIb} \beta 3$ and $\alpha v \beta 3$ are related in that they share the $\alpha$ subunit and have homologous $\beta$ subunits (Pytela et al. 1986). More importantly, $\alpha \operatorname{IIb} \beta 3$ is a key player in platelet aggregation and antagonism of $\alpha \operatorname{Irb} \beta 3$ would be expected to cause unwanted bleeding problems (Coller et al. 1989). Through screening and medicinal chemistry, SC-56631 and SC65811 , two potent antagonists of $\alpha \mathrm{v} \beta 3$, were produced. SC-56631 inhibited vitronectin and fibrinogen binding to $\alpha v \beta 3$ and $\alpha \operatorname{IIb} \beta 3$ respectively with similar potency, but SC-65811 was at least 100 times more potent as an inhibitor of $\alpha v \beta 3$ than of $\alpha \operatorname{IIb} \beta 3$. As described above, Engleman and colleagues (1997) showed that SC-56631 inhibited bone loss in ovariectomized rodents and therefore it was not surprising to observe that SC-56631 and SC-65811 inhibited osteoclast adhesion and bone resorption in vitro.

SC-56631 and SC-65811 inhibited rabbit osteoclast adhesion to immobilized ECM, caused adherent and wellspread osteoclasts to retract and round up from surfaces coated with matrix and inhibited bone resorption. On the basis of these results, the activities of SC-56631 and SC65811 appeared to be similar to the anti- $\alpha v \beta 3$ and bone resorption inhibiting activities previously reported for RGD-based peptides and echistatin, with the distinction that SC-65811 is clearly both more potent than SC-56631 and selective for $\alpha \mathrm{v} \beta 3$ rather than $\alpha \operatorname{Irb} \beta 3$. In contrast, however, we were surprised to note that SC-56631 and SC-65811 inhibited bone resorption in a dose-responsive 


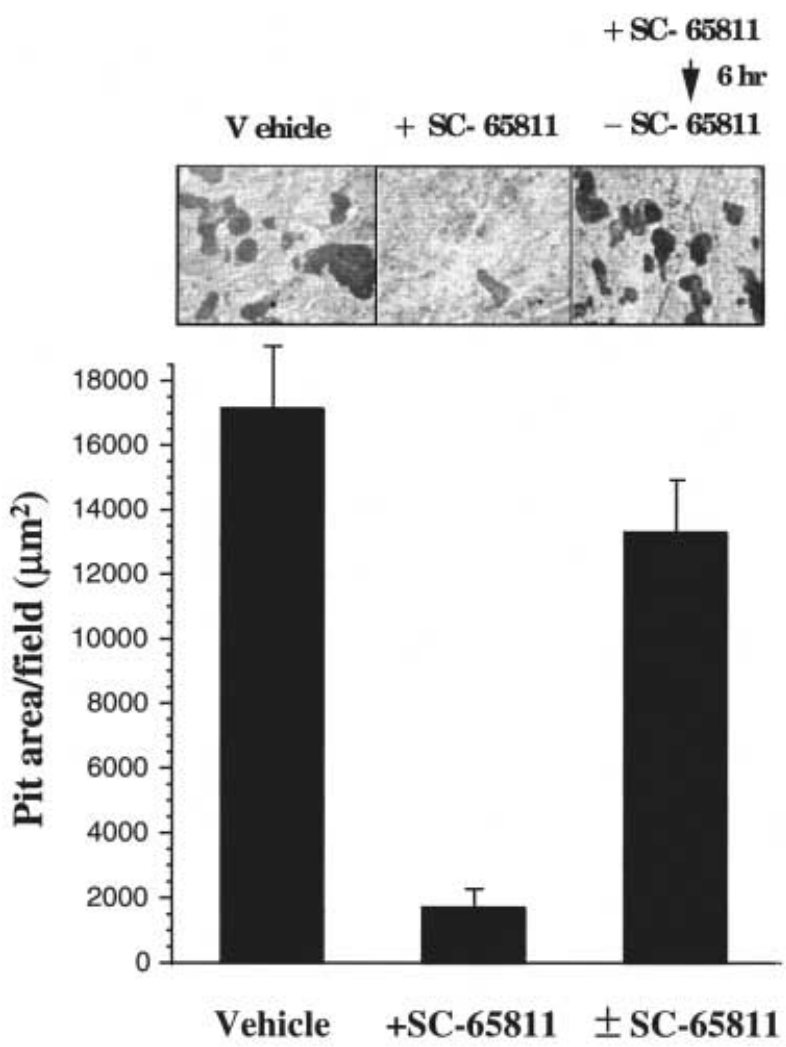

Figure 5 Inhibition of osteoclast bone resorptive activity by SC-65811. Osteoclasts were plated on bone slices in the presence of $20 \mu \mathrm{M}$ SC- 65811 and incubated for $6 \mathrm{~h}$ at $37^{\circ} \mathrm{C}$. Bone slices were transferred to wells containing a mixture of fresh media and compound and incubated for an additional 3 days or they were washed twice with fresh media to remove compound and nonadherent cells and incubated in media lacking compound for additional 3 days. At the end of the incubation period, bone pieces were washed with $\mathrm{NH}_{4} \mathrm{OH}$ to remove adherent cells and the number of resorptive pits and the resorptive pit area per field quantitated using dark-field microscopy. The inset photomicrograph shows representative reflected-light images of the bone surface after removal of cells. The darkened areas represent osteoclast resorption lacunae. The error bars represent the mean \pm S.E.M. Osteoclasts treated continuously with SC-65811 resorbed significantly less bone than cells treated with vehicle $(P<0 \cdot 001)$. In contrast, resorptive activity was not significantly affected by transient exposure to SC-65811 $\left(17112 \mu \mathrm{m}^{2}\right.$ compared with $\left.13271 \mu \mathrm{m}^{2} ; P>0.05\right)$. However, continuous treatment of osteoclasts with SC-65811 reduced the number of resorption pits produced by $67 \%(P<0.01)$ and average resorptive pit area by $70 \%(P<0.01)$ compared with vehicle-treated cells (data not shown).

manner but did not significantly affect osteoclast adhesion to bone. Further analysis showed that SC-65811 decreased the number and average pit area produced per osteoclast and suggested that $\alpha \mathrm{v} \beta 3$ antagonists inhibit bone resorption by decreasing osteoclast bone resorptive activity or efficiency.

Rodan and colleagues have recently reported that echistatin inhibited bone resorption in thyroparathyroid- ectomized mice (Masarachia et al. 1998) and ovariectomized mice and rats (Yamamoto et al. 1998). Using histomorphometric techniques, these investigators showed that echistatin treatment did not detectably alter osteoclast morphology but increased the bone surface covered by osteoclasts - results suggesting that echistatin treatment did not reduce osteoclast formation, recruitment, or attachment to bone but did, nevertheless, inhibit bone resorption. Our in vitro observations on the effects of SC-56631 and SC-65811 on osteoclast bone resorption agree with these findings of Rodan and colleagues and are consistent with the hypothesis that RGD-containing proteins and peptidomimetics inhibit bone resorption by reducing osteoclast bone resorptive activity.

Previous studies showed that RGD peptides and echistatin inhibited chicken and rat osteoclast adhesion to bone and bone resorption in vitro (Sato et al. 1990, 1994, Ross et al. 1993). In contrast, we have shown that osteoclasts can adhere to bone in the presence of echistatin, SC-56631 and SC-65811. The differences between the reported effects that these antagonists have on osteoclast adhesion to bone could be due to differences in the response of rat, chicken and rabbit osteoclasts to the test compounds utilized in the various studies or to the manner in which osteoclast attachment was determined. In the studies by Sato et al. (1990) and Ross et al. (1993) $\left[{ }^{3} \mathrm{H}\right]$-labeled bone particles were added to chicken osteoclasts attached to ECM or bone. The hydrolysis of bone and release of ${ }^{3} \mathrm{H}$ from bone particles, presumably bound to the basolateral osteoclast surface, were determined by scintillation counting. Alternatively, Sato et al. (1994) used laser confocal microscopy and epifluorescence to show that treatment of rat osteoclasts with echistatin caused changes in cellular morphology, cell rounding, echistatin receptor redistribution and alterations in morphology suggestive of cell detachment. These techniques differ significantly from the direct determination of osteoclasts adherent to bone substrate that was used in the studies presented herein. It should be noted that, in contrast to the reports of Sato et al. (Sato et al. 1990, 1994) and Ross et al. (1993), Rodan and co-workers (Masarachia et al. 1998, Yamamoto et al. 1998) recently showed that osteoclasts of mice and rats treated with echistatin in vivo appeared normal and showed no signs of altered cell morphology or detachment but, rather, the bone surface area covered by osteoclasts was increased in animals treated with echistatin, implying that echistatin did not impair osteoclast recruitment and attachment to bone. Together, these findings support the notion that bone resorption is more sensitive to echistatin than is cell attachment (Sato et al. 1994).

These results underscore the notion that integrinmediated mechanisms function in the bone resorptive process. The integrin $\alpha \mathrm{v} \beta 3$ has been implicated in several aspects of osteoclast interaction with bone, including the formation of the osteoclast clear zone and cell migration. Resorbing osteoclasts develop a specialized membrane 
A. SC-56631

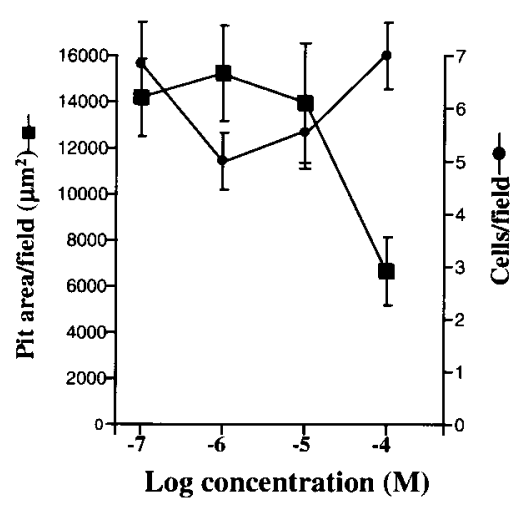

B. SC-65811

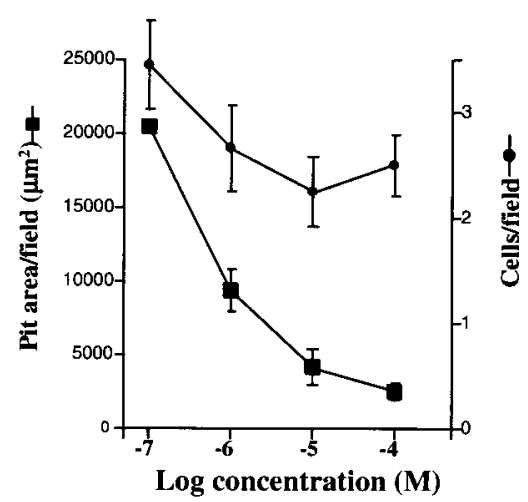

Figure 6 SC-56631 and SC-65811 inhibit bone resorption. Various concentrations of SC-56631 and SC-65811 were combined with osteoclasts and then added to 12-well plates containing bovine bone pieces. The cells were allowed to adhere and then the bone pieces were transferred to fresh media containing SC-56631 or SC-65811 and incubated for an additional 3 days. Osteoclasts cultured on bones slices were fixed and stained for TRAP. The number of TRAP+, multinucleated cells for each treatment was obtained by examination of 10 random fields per bone piece; two bone pieces were used for each compound concentration tested. Bone pieces were then washed with $\mathrm{NH}_{4} \mathrm{OH}$ to remove cells and the number and the resorptive pit area were quantified using dark-field reflective microscopy. The number of osteoclasts per field and the resorptive pit area per field were determined. The error bars represent the mean \pm S.E.M. Compared with vehicle-treated osteoclasts, SC-65811 inhibited bone resorption by $54 \%(P>0 \cdot 05), 79 \%(P<0 \cdot 001)$ and $88 \%$ $(P<0 \cdot 001)$ at $1 \mu \mathrm{M}, 10 \mu \mathrm{M}$ and $100 \mu \mathrm{M}$ respectively. SC-56631 significantly inhibited resorption by $53 \%$ at $100 \mu \mathrm{M}(P<0 \cdot 05)$. The number of osteoclasts adherent to bone slices treated with various concentrations of SC-56631 and SC-65811 compared with vehicle was not significantly different (Kruskal-Wallis test, $P=0 \cdot 166$ ).

domain termed the clear zone or tight sealing zone, which is believed to mediate cell attachment to the bone matrix isolating the acidic resorption lacunae from the extracellular environment. Localization studies showed that $\alpha v \beta 3$ and osteopontin were enriched in the clear zone of resorbing osteoclasts and the underlying bone matrix (Reinholt et al. 1990, Hultenby et al. 1993) and, together with the observations that integrin antagonists inhibit osteoclast attachment to surfaces coated with ECM proteins, suggested that $\alpha v \beta 3$ plays a role in the formation or maintenance of the tight sealing zone. However, more recent localization studies have been unable to confirm the presence of $\alpha v \beta 3$ within the sealing zone and it is now clear that osteopontin is not found exclusively in the bone matrix beneath the sealing zone (Lakkakorpi et al. 1991, 1993, Rodan \& Rodan 1997). Indeed, more recent studies

Table 1 SC-65811 inhibits osteoclast bone resorption by isolated rabbit osteoclasts

\begin{tabular}{|c|c|c|c|c|c|c|}
\hline & $\begin{array}{l}\text { Cell no. } \\
\text { per field" }\end{array}$ & $\begin{array}{l}\text { Pit area } \\
\text { per field }\end{array}$ & $\begin{array}{l}\% \text { of } \\
\text { control }\end{array}$ & $\begin{array}{l}\text { Pit no. } \\
\text { per field* }\end{array}$ & $\begin{array}{l}\text { Pit no. } \\
\text { per cell }\end{array}$ & $\begin{array}{l}\text { Pit area } \\
\text { per cell }\end{array}$ \\
\hline $\begin{array}{l}\text { Vehicle } \\
\text { SC-65811 }\end{array}$ & $3 \cdot 45$ & 20345 & 100 & 6.75 & 1.96 & 5938 \\
\hline $1 \mu \mathrm{m}$ & $2 \cdot 65$ & 9365 & 46 & $4 \cdot 70$ & $1 \cdot 77$ & 3533 \\
\hline $10 \mu \mathrm{m}$ & $2 \cdot 25$ & 4195 & 20 & $1 \cdot 55$ & 0.69 & 1864 \\
\hline $100 \mu \mathrm{m}$ & $2 \cdot 50$ & 2532 & 12 & $2 \cdot 10$ & $0 \cdot 84$ & 1013 \\
\hline
\end{tabular}

\#Tota number of osteoclasts counted in 20 fields divided by the number of fields.

Total area $\left(\mu \mathrm{m}^{2}\right)$ counted in 20 fields divided by the number of fields.

*Total number of resorptive pits counted in 20 fields divided by the number of fields.

†Pit no. divided by the cell no.

†Pit area per field divided by the cell no. per field.

${ }^{\S} \mathrm{SC}-658111 \mu \mathrm{m}, 10 \mu \mathrm{m}$ and $100 \mu \mathrm{m}$ decreased the number of resorption pits produced by

$31 \%(P>0.05), 77 \%(P<0 \cdot 001)$ and $69 \%(P<0 \cdot 001)$ respectively. 


\section{A. Osteopontin}

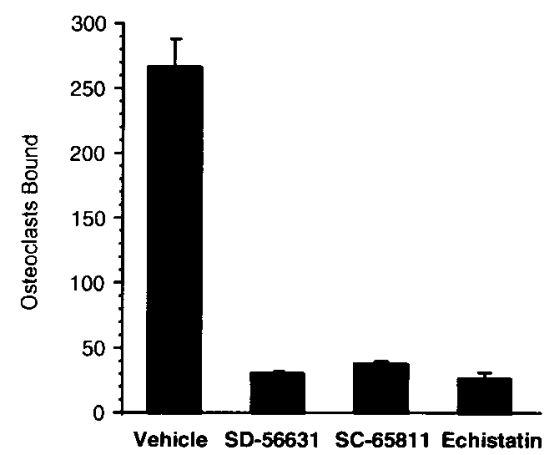

B. Bone

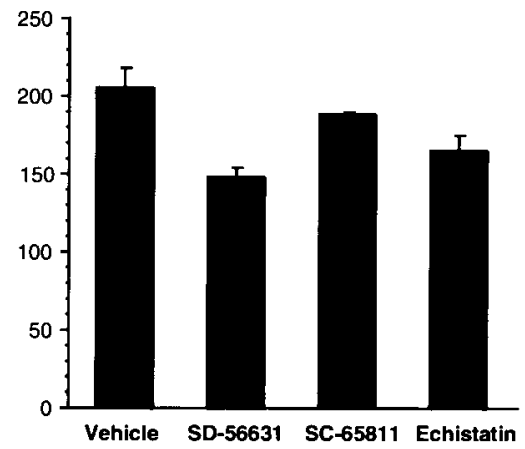

Figure 7 SC-56631, SC-65811 and echistatin inhibit osteoclast adhesion to osteopontin but not to bone. Osteoclasts were diluted in $\alpha$-MEM containing SC-56631 (100 $\mu \mathrm{M})$, SC-65811 $(100 \mu \mathrm{M})$ or echistatin $(100 \mathrm{nM})$ and added to osteopontin-coated 96-well plates or to wells containing bone slices. The cells were incubated at $37^{\circ} \mathrm{C}$ for $1 \mathrm{~h}$ and then washed to remove non-adherent cells. The number of bound osteoclasts was determined as described in the Materials and Methods. The error bars represent the mean \pm S.E.M.

demonstrate that $\alpha \mathrm{v} \beta 3$ is localized to the osteoclast basolateral surface and ruffled border (Lakkakorpi et al. 1991, 1993, Helfrich et al. 1996) - a location consistent with a role for $\alpha v \beta 3$ in osteoclast cell migration.

Classically, the role ascribed to integrins has been that of anchoring cells to the ECM. However, recent reports showed that the interaction between the ECM and cell surface integrins leads to intracellular signaling events that affect cell migration (Uhm et al. 1999). There is abundant evidence that the integrin $\alpha v \beta 3$ plays a role in the migration of a variety of cells including tumor cells (Leavesley et al. 1992, Filardo et al. 1995, 1996, Zheng et al. 1999), smooth muscle cells (Brown et al. 1994, Yue et al. 1994, Liaw et al. 1995, Jones et al. 1996, van Leeuwen et al. 1996, Senger \& Perruzzi 1996, Stefansson \& Lawrence 1996), neutrophils (Lawson \& Maxfield 1995) and endothelial cells (Leavesley et al. 1993, Senger et al. 1996). It seems likely that antagonists of $\alpha v \beta 3$ reduce the ability of the osteoclast to migrate on bone substrates and thereby interfere with the bone resorptive process. It is important to note that treatment of osteoclasts with SC-65811 significantly reduced the number of resorption pits produced per osteoclast and the average pit size, and it is conceivable that the reduction in pit number and size is a consequence of inhibiting osteoclast cell migration.

In summary, we show that $\alpha v \beta 3$ antagonists potently inhibit osteoclast adhesion to purified bone matrix protein and osteoclast-mediated bone resorption but do not inhibit osteoclast adhesion to bone. We conclude that $\alpha \mathrm{v} \beta 3$ antagonists inhibit bone resorption by inhibiting osteoclastic bone resorptive activity. Antagonists of $\alpha \mathrm{v} \beta 3$ may offer an exciting new therapeutic opportunity for the prevention of bone loss in disease states that include osteoporosis and metastatic bone cancer.

\section{Acknowledgements}

We are grateful to Drs Philip Osdoby, Patricia CollinOsdoby and Teresa Sunyer at Washington University for help in analyzing the results of bone resorption experiments. We wish to thank Dr Alfred Balch, Searle Preclinical Statistics for help with statistical analysis.

\section{References}

Brown SL, Lundgren CH, Nordt T \& Fujii S 1994 Stimulation of migration of human aortic smooth muscle cells by vitronectin: implications for atherosclerosis. Cardiovascular Research $\mathbf{2 8}$ 1815-1820.

Butler WT 1989 The nature and significance of osteopontin. Connective Tissue Research 23 123-136.

Carron CP, Meyer DM, Pegg JA, Engleman VW, Nickols MA, Settle SL, Westlin WF, Ruminski PG \& Nickols G A 1998 A peptidomimetic antagonist of the integrin $\alpha_{v} \beta 3$ inhibits Leydig cell tumor growth and the development of hypercalcemia of malignancy. Cancer Research 58 1930-1935.

Chambers TJ, Fuller K, Darby JA, Pringle JA \& Horton MA 1986 Monoclonal antibodies against osteoclasts inhibit bone resorption in vitro. Bone and Mineral 1 127-135.

Cheresh DA \& Spiro RC 1987 Biosynthetic and functional properties of an Arg-Gly-Asp-directed receptor involved in human melanoma cell attachment to vitronectin, fibrinogen, and von Willebrand factor. Journal of Biological Chemistry 262 17703-17711.

Chuntharapai A, Bodary S, Horton M \& Kim KJ 1993 Blocking monoclonal antibodies to $\alpha v \beta 3$ integrin: a unique epitope of $\alpha v \beta 3$ integrin is present on human osteoclasts. Experimental Cell Research 205 345-352.

Clezardin P, Jouishomme H, Chavassieux P \& Marie PJ 1989 Thrombospondin is synthesized and secreted by human osteoblasts and osteosarcoma cells. A model to study the different effects of thrombospondin in cell adhesion. European Journal of Biochemistry $181721-726$.

Coller BS, Folts JD, Smith SR, Scudder LE \& Jordan R 1989 Abolition of in vivo platelet thrombus formation in primates with 
monoclonal antibodies to the platelet GPIIb/IIIa receptor. Correlation with bleeding time, platelet aggregation, and blockade of GPIIb/IIIa receptors. Circulation 80 1766-1774.

Collin-Osdoby P, Oursler MJ, Rothe L, Webber D, Anderson F \& Osdoby P 1995 Osteoclast 121F antigen expression during osteoblast conditioned medium induction of osteoclast-like cells in vitro: relationship to calcitonin responsiveness, tartrate resistant acid phosphatase levels, and bone resorptive activity. Journal of Bone and Mineral Research 10 45-58.

Crippes BA, Engleman VW, Settle SL, Delarco J, Ornberg RL, Helfrich MH, Horton MA \& Nickols GA 1996 Antibody to $\beta-3$ integrin inhibits osteoclast-mediated bone resorption in the thyroparathyroidectomized rat. Endocrinology 137 918-924.

Davies J, Warwick J, Totty N, Philp R, Helfrich M \& Horton M 1989 The osteoclast functional antigen, implicated in the regulation of bone resorption, is biochemically related to the vitronectin receptor. Journal of Cell Biology 109 1817-1826.

Engleman VW, Nickols GA, Ross FP, Horton MA, Griggs DW, Settle SL, Ruminski PG \& Teitelbaum SL 1997 A peptidomimetic antagonist of the $\alpha v \beta 3$ integrin inhibits bone resorption in vitro and prevents osteoporosis in vivo. Journal of Clinical Investigation 99 2284-2292.

Filardo EJ, Brooks PC, Deming SL, Damsky C \& Cheresh DA 1995 Requirement of the NPXY motif in the integrin $\beta 3$ subunit cytoplasmic tail for melanoma cell migration in vitro and in vivo. Journal of Cell Biology 130 441-450.

Filardo EJ, Deming SL \& Cheresh DA 1996 Regulation of cell migration by the integrin $\beta$ subunit ectodomain. Journal of Cell Science 109 1615-1622.

Fisher JE, Caulfield MP, Sato M, Quartuccio HA, Gould RJ, Garsky VM, Rodan GA \& Rosenblatt M 1993 Inhibition of osteoclastic bone resorption in vivo by echistatin, an 'arginyl-glycyl-aspartyl' (RGD)-containing protein. Endocrinology 132 1411-1413.

Flores ME, Norgard M, Heinegard D, Reinholt FP \& Andersson G 1992 RGD-directed attachment of isolated rat osteoclasts to osteopontin, bone sialoprotein, and fibronectin. Experimental Cell Research 201 526-530.

Grano M, Zigrino P, Colucci S, Zambonin G, Trusolino L, Serra M, Baldini N, Teti A, Marchisio PC \& Zallone AZ 1994 Adhesion properties and integrin expression of cultured human osteoclast-like cells. Experimental Cell Research 212 209-218.

Helfrich MH, Nesbitt SA, Dorey EL \& Horton MA 1992 Rat osteoclasts adhere to a wide range of RGD (Arg-Gly-Asp) peptidecontaining proteins, including the bone sialoproteins and fibronectin, via a $\beta-3$ integrin. Journal of Bone and Mineral Research 7 335-343.

Helfrich MH, Nesbitt SA, Lakkakorpi PT, Barnes MJ, Bodary SC, Shankar G, Mason WT, Mendrick DL, Vaananen HK \& Horton MA 1996 -1 integrins and osteoclast function: involvement in collagen recognition and bone resorption. Bone 19 317-328.

Horton MA \& Rodan GA 1996 Integrins as Therapeutic Targets in Bone Disease. Boca Raton: CRC Press.

Horton MA, Taylor ML, Arnett TR \& Helfrich MH 1991 Arg-GlyAsp (RGD) peptides and the anti-vitronectin receptor antibody $23 \mathrm{C} 6$ inhibit dentine resorption and cell spreading by osteoclasts. Experimental Cell Research 195 368-375.

Horton MA, Dorey EL, Nesbitt SA, Samanen J, Ali FE, Stadel JM, Nichols A, Greig R \& Helfrich MH 1993 Modulation of vitronectin receptor-mediated osteoclast adhesion by Arg-Gly-Asp peptide analogs: a structure-function analysis. Journal of Bone and Mineral Research 8 239-247.

Hultenby K, Reinholt FP \& Heinegard D 1993 Distribution of integrin subunits on rat metaphyseal osteoclasts and osteoblasts. European Journal of Cell Biology 62 86-93.

Jones JI, Prevette T, Gockerman A \& Clemmons DR 1996 Ligand occupancy of the $\alpha \mathrm{v} \beta 3$ integrin is necessary for smooth muscle cells to migrate in response to insulin-like growth factor. PNAS $\mathbf{9 3}$ 2482-2487.
Kanehisa J \& Heersche JN 1988 Osteoclastic bone resorption: in vitro analysis of the rate of resorption and migration of individual osteoclasts. Bone 9 73-79.

King KL, D'Anza JJ, Bodary S, Pitti R, Siegel M, Lazarus RA, Dennis MS, Hammonds RG Jr \& Kukreja SC 1994 Effects of kistrin on bone resorption in vitro and serum calcium in vivo. Journal of Bone and Mineral Research 9 381-387.

Lakkakorpi PT \& Vaananen HK 1991 Kinetics of the osteoclast cytoskeleton during the resorption cycle in vitro. Journal of Bone and Mineral Research 6 817-826.

Lakkakorpi PT, Horton MA, Helfrich MH, Karhukorpi EK \& Vaananen HK 1991 Vitronectin receptor has a role in bone resorption but does not mediate tight sealing zone attachment of osteoclasts to the bone surface. Journal of Cell Biology 115 1179-1186.

Lakkakorpi PT, Helfrich MH, Horton MA \& Vaananen HK 1993 Spatial organization of microfilaments and vitronectin receptor, $\alpha \mathrm{v} \beta 3$, in osteoclasts. A study using confocal laser scanning microscopy. Journal of Cell Science 104 663-670.

Lawson MA \& Maxfield FR $1995 \mathrm{Ca}^{2+}$ - and calcineurin-dependent recycling of an integrin to the front of migrating neutrophils. Nature 377 75-79.

Leavesley DI, Ferguson GD, Wayner EA \& Cheresh DA 1992 Requirement of the integrin $\beta 3$ subunit for carcinoma cell spreading or migration on vitronectin and fibrinogen. Journal of Cell Biology 117 1101-1107.

Leavesley DI, Schwartz MA, Rosenfeld M \& Cheresh DA 1993 Integrin $\beta 1$ - and $\beta 3$-mediated endothelial cell migration is triggered through distinct signaling mechanisms. Journal of Cell Biology 121 $163-170$.

van Leeuwen RL, Yoshinaga IG, Akasaka T, Dekker SK, Vermeer BJ \& Byers HR 1996 Attachment, spreading and migration of melanoma cells on vitronectin. The role of $\alpha \mathrm{v} \beta 3$ and $\alpha \mathrm{v} \beta 5$ integrins. Experimental Dermatology 5 308-315.

Liaw L, Skinner MP, Raines EW, Ross R, Cheresh DA, Schwartz SM \& Giachelli CM 1995 The adhesive and migratory effects of osteopontin are mediated via distinct cell surface integrins. Role of $\alpha v \beta 3$ in smooth muscle cell migration to osteopontin in vitro. Journal of Clinical Investigation 95 713-724.

Masarachia P, Yamamoto M, Leu CT, Rodan G \& Duong L 1998 Histomorphometric evidence for echistatin inhibition of bone resorption in mice with secondary hyperparathyroidism. Endocrinology 139 1401-1410.

Minkin C 1982 Bone acid phosphatase: tartrate-resistant acid phosphatases as a marker of osteoclast function. Calcified Tissue International 285 285-289.

Pytela R, Pierschbacher MD, Ginsberg MH, Plow EF \& Ruoslahti E 1986 Platelet membrane glycoprotein IIb/IIIa: member of a family of Arg-Gly-Asp-specific adhesion receptors. Science 231 1559-1562.

Pytela R, Pierschbacher MD, Argraves S, Suzuki S \& Ruoslahti E 1987 Arginine-glycine-aspartic acid adhesion receptors. Methods in Enzymology 144 475-489.

Reinholt FP, Hultenby K, Oldberg A \& Heinegard D 1990 Osteopontin - a possible anchor of osteoclasts to bone. PNAS 87 4473-4475.

Robey PG, Young MF, Fisher LW \& McClain TD 1989 Thrombospondin is an osteoblast-derived component of mineralized extracellular matrix. Journal of Cellular Biology 108 719-727.

Rodan SB \& Rodan GA 1997 Integrin function in osteoclasts. Journal of Endocrinology 154 S47-S56.

Ross FP, Chappel J, Alvarez JI, Sander D, Butler WT, Farach Carson MC, Mintz KA, Robey PG, Teitelbaum SL \& Cheresh DA 1993 Interactions between the bone matrix proteins osteopontin and bone sialoprotein and the osteoclast integrin $\alpha v \beta 3$ potentiate bone resorption. Journal of Biological Chemistry 268 9901-9907.

Ruoslahti E 1996 RGD and other recognition sequences for integrins. Annual Review of Cell and Developmental Biology 12 697-715. 
Sato M, Sardana MK, Grasser WA, Garsky VM, Murray JM \& Gould RJ 1990 Echistatin is a potent inhibitor of bone resorption in culture. Journal of Cell Biology 111 1713-1723.

Sato M, Garsky V, Majeska RJ, Einhorn TA, Murray J, Tashjian AH Jr \& Gould RJ 1994 Structure-activity studies of the s-echistatin inhibition of bone resorption. Journal of Bone and Mineral Research 9 1441-1449.

Senger DR \& Perruzzi CA 1996 Cell migration promoted by a potent GRGDS-containing thrombin-cleavage fragment of osteopontin. Biochimica et Biophysica Acta 1314 13-24.

Senger DR, Ledbetter SR, Claffey KP, Papadopoulos Sergiou A, Peruzzi CA \& Detmar M 1996 Stimulation of endothelial cell migration by vascular permeability factor/vascular endothelial growth factor through cooperative mechanisms involving the $\alpha v \beta 3$ integrin, osteopontin, and thrombin. American Journal of Pathology 149 293-305.

Stefansson S \& Lawrence DA 1996 The serpin PAI-1 inhibits cell migration by blocking integrin $\alpha \mathrm{v} \beta 3$ binding to vitronectin. Nature 383 441-443.

Uhm JH, Gladson CL \& Rao JS 1999 The role of integrins in the malignant phenotype of gliomas. Frontiers in Bioscience $\mathbf{4}$ D188-D199.
Wong NC, Mueller BM, Barbas CF, Ruminski P, Quaranta V, Lin EC \& Smith JW 1998 av Integrins mediate adhesion and migration of breast carcinoma cell lines. Clinical and Experimental Metastasis $\mathbf{1 6}$ $50-61$.

Yamamoto M, Fisher JE, Gentile M, Seedor JG, Leu CT, Rodan SB \& Rodan GA 1998 The integrin ligand echistatin prevents bone loss in ovariectomized mice and rats. Endocrinology 139 1411-1419.

Yue TL, McKenna PJ, Ohlstein EH, Farach Carson MC, Butler WT, Johanson K, McDevitt P, Feuerstein GZ \& Stadel JM 1994 Osteopontin-stimulated vascular smooth muscle cell migration is mediated by $\beta 3$ integrin. Experimental Cell Research 214 459-464.

Zheng DQ, Woodard AS, Fornaro M, Tallini G \& Languino LR 1999 Prostatic carcinoma cell migration via $\alpha v \beta 3$ integrin is modulated by a focal adhesion kinase pathway. Cancer Research 59 $1655-1664$.

Received 25 June 1999

Revised manuscript received 4 January 2000

Accepted 20 January 2000 